\title{
Hepatic and portal-drained viscera balances of amino acids, insulin, glucagon and gastrin in the pig after ingestion of casein or rapeseed proteins
}

\author{
C Simoes Nunes 1*, I Galibois 2, A Rérat 1, \\ L Savoie 2, P Vaugelade 1 \\ 1 Département de Nutrition, Alimentation, Sécurité Alimentaire, Bât 405, INRA-CRJ, \\ 78350 Jouy-en-Josas, France; \\ 2 Département de Nutrition Humaine et de Consommation, FSAA, Université Laval, \\ Québec, G1K 7P4 Canada
}

(Received June 6 1990; accepted December 28 1990)

\begin{abstract}
Summary - Hepatic and intestinal balances of amino acids, insulin, glucagon and gastrin were studied in 6 non-anaesthetized Large White pigs (mean body weight $64 \pm 4.8 \mathrm{~kg}$ ) after ingestion of casein or rapeseed proteins. The animals were fitted with permanent catheters in the portal vein, the brachiocephalic artery and the right hepatic vein. In addition, 2 electromagnetic flow probes were implanted, one around the portal vein and the other around the hepatic artery. After a preliminary adaptation to each diet the animals received at 1-wk intervals and according to a double latin square design, 3 test meals of $800 \mathrm{~g}$ each, one containing $23.2 \%$ of rapeseed concentrate (diet RA 12) and the others 13.9 or $27.8 \%$ of hydrochloric casein (diets CA 12 and CA 24). Each observation period lasted $12 \mathrm{~h}$.

Amino acids from all diets were very well absorbed. In $12 \mathrm{~h}$, the absorption of total amino acids as a percentage of the ingested quantities was $99 \%$ for CA 12, 102\% for CA 24 and $104 \%$ for RA 12. Hepatic uptake of total amino acids in $12 \mathrm{~h}$ expressed as a percentage of the absorbed quantities was $13 \%$ for CA $12,66 \%$ for CA 24 and $25 \%$ for RA 12. Differences in the hepatic extraction rate of essential amino acids appeared between the 2 levels of casein ingestion and for Arg between the 2 protein sources. Whatever the nature of the ingested protein or the level of casein, the liver showed a net production of Asp and Glu. The production and hepatic balance of insulin were the lowest after ingestion of RA 12. No differences were noted in the same parameters for glucagon and gastrin. Independently of the nutritional situation, the hepatic extraction rate of insulin appeared to be higher than those of glucagon and gastrin.

Our results showed that the nature as well as the level of dietary proteins have large effects on the sequence and volume of absorptive phenomena, the hepatic metabolism of nutrients, the production of gastrointestinal hormones and the non-hepatic tissue disposal of absorbed nutrients.
\end{abstract}

amino acids / liver / balance / insulin / pig

Résumé - Bilans hépatiques et intestinaux des acides aminés, de l'insuline, du glucagon et de la gastrine chez le porc après ingestion de caséine ou de protéines de colza. Les bilans hépatiques et intestinaux des acides aminés, de l'insuline, du glucagon et de la gastrine ont été étudiés

\footnotetext{
" Correspondence and reprints. Present address: Société Chimique Roch, BP 170, 68305 SaintLouis Cedex, France
} 
chez 6 porcs Large White non anesthésiés $(64 \pm 4,8 \mathrm{~kg}$ de poids vif initial) après ingestion de caséine ou de protéines de colza. Les animaux ont été munis de cathéters permanents placés dans la veine hépatique droite, la veine porte et l'artère carotide et de sondes débitmétriques autour de la veine porte et de l'artère hépatique. Après une adaptation préliminaire à chaque régime les animaux ont reçu, à 1 semaine d'intervalle et selon un dispositif en carré latin, 3 repas-test de $800 \mathrm{~g}$ chacun, l'un contenant $23,2 \%$ de concentrat de colza (régime RA 12) et les autres $13,9 \%$ et $27,8 \%$ de caséine chlorhydrique (régimes CA 12 et CA 24). Chaque période d'observation a duré $12 \mathrm{~h}$.

Les acides aminés des 3 régimes ont été très bien absorbés. L'absorption en $12 \mathrm{~h}$ des acides aminés totaux a été, en pourcentage des quantités ingérées, de $99 \%$ pour $C A 12$, de 102\% pour CA 24 et de 104\% pour RA 12. La captation hépatique en $12 \mathrm{~h}$ des acides aminés totaux exprimée en pourcentage des quantités absorbées a été de 13\% pour CA 12, de 66\% pour CA 24 et de $25 \%$ pour RA 12. Des différences dans le taux d'extraction hépatique des acides aminés essentiels sont apparues entre les 2 taux d'ingestion de caséine et pour l'Arg entre les 2 sources protéiques. Quels que soient la nature de la protéine ingérée et le taux d'ingestion de caséine, le foie a exhibé une production nette d'Asp, et de Glu. La production et le bilan hépatique de l'insuline ont été les plus faibles après l'ingestion de RA 12. Aucune différence n'a été observée dans les mêmes paramètres pour ce qui se rapporte au glucagon et à la gastrine. Indépendamment de la situation nutritionnelle, le taux d'extraction hépatique de l'insuline est apparu beaucoup plus élevé que ceux du glucagon et de la gastrine.

L'ensemble des résultats indique que la nature aussi bien que le taux des protéines dans l'alimentation ont des effets importants sur la séquence et le volume des phénomènes absorptifs des différents constituants du régime, sur la métabolisation hépatique des nutriments, sur la production d'hormones gastro-intestinales et sur la mise à la disposition des tissus extra-hépatiques des nutriments absorbés.

acides aminés / foie / bilan / insuline / porc

\section{INTRODUCTION}

The splanchnic area plays a fundamental role in the supply of dietary nutrients to the rest of the body. In vivo studies of splanchnic area metabolism require the utilization of techniques for quantitative determination of metabolic and hormonal fluxes across the liver and portal drained viscera. Such techniques, based on the catheterization of a hepatic vein, the portal vein and of one artery as well as in the use of devices permitting measurement of the blood flow rate in the liver vessels (portal vein and hepatic artery) are now available in the sheep (Bergman and Heitmann, 1978), cow (Lomax and Baird, 1983), dog (Cherrington et al, 1982), rabbit (Pere et al, 1987) and pig (Simoes Nunes et al, $1984,1989)$. In the latter species, there are numerous experimental data on the fluxes of nutrients and other substrates in the portal-drained viscera (Rérat et al, $1984,1985)$. However, the hepatic fluxes have only considered some substrates (Simoes Nunes et al, 1989). Estimation of amino acid fluxes in the splanchnic area has been made in the dog (Elwyn et al, 1968; Barrett et al, 1986) whilst in other species including man (Wahren et al, 1976) the data are either very fragmentary or inexistent. Consequently, our knowledge on the splanchnic amino acids fluxes according to the source of ingested protein and level of ingestion is very limited. The aim of the present work was to evaluate the entering and leaving liver fluxes of amino acids in the pig, the role of the liver in their metabolism as well as in that of 3 hormones from the splanchnic area-insulin, glucagon and gastrin-after ingestion of 2 very different proteins, casein and rapeseed concentrate, incorporated into the diet a normal level (12\%) or for casein, at a high level (24\%). 


\section{MATERIAL AND METHODS}

\section{Animals and diets}

Six castrated Large White pigs $(64 \pm 4.8 \mathrm{~kg}$ initial body weight) were used. The animals were fitted with 3 catheters, placed in the portal vein, brachiocephalic artery and right hepatic vein, respectively as well as with 2 electromagnetic flow probes, one around the portal vein and the other around the hepatic artery as described by Simoes Nunes et al (1989). In order to obtain reproducible data when measuring various hepatic metabolic fluxes, the hepatic vein catheter must be well fixed. Without adequate radiological means, the only way of verifying the adequacy of the procedure is by the peri-hepatic palpation of the posterior vena cava during surgery. After recovering from surgery, and with a preliminary adaptation to each diet, the animals received at 1-wk intervals and according to a double latin square design, 3-test meals of $800 \mathrm{~g}$ each, one containing $23.2 \%$ rapeseed concentrate (diet RA 12) and the others 13.9 or $27.8 \%$ hydrochloric casein (diets CA 12 and CA 24). Diet compo- sition is given in table I. The ingested quantities of amino acids are shown in table II. Throughout the experimental period the animals were kept individually in cages which permitted easy access to the cannulae and probes.

\section{Measurements}

The test meals were offered to the animals at $09.00 \mathrm{~h}$ after a fasting period of $24 \mathrm{~h}$. Portal vein and hepatic artery blood flow-rates were recorded continuously during a post-prandial period of $12 \mathrm{~h}$. During the same time blood was sampled simultaneously from the hepatic vein, brachiocephalic artery and portal vein $(6 \mathrm{ml} / \mathrm{site})$. The samples were withdrawn at 15 -min intervals during the 1 st $h$ following the meal, then every 30 min during the 2nd and 3rd $h$ and once every hour afterwards. Five $\mathrm{ml}$ of each blood sample were collected for plasma immunoreactive insulin, glucagon and gastrin measurements in icechilled tubes containing $20 \mu \mathrm{l}$ heparin (100 IU) and $1000 \mathrm{KIU}$ Trasylol (apronitin)/ml blood. Plasma samples were rapidly prepared after centrifugation (1600 $\mathrm{g}, 4^{\circ}, 15 \mathrm{~min}$ ) and stored at

Table I. Composition of experimental diets (\%).
CA 12
CA 24
RA 12

Hydrochloric casein (UCCP)
Rapeseed concentrate (CETIOM)
Peanut oil
Maize starch
Purified cellulose
Mica powder
Mineral mixture 1
Vitamin mixture 2
Antioxidant

13.9
-
6
65.5
6
5
2.5
1
0.1

27.8
-
3
54.6
6
5
2.5
1
0.1
23.2
3
62.7
2.5
5
2.5
1

0.1

Dry matter content in percent of fresh matter: CA $12=89.26 \% ;$ CA $24=89.05 \% ;$ RA $12=88.69 \%$. Energy content ( $\mathrm{kJ} / \mathrm{g}$ dry matter): CA $12=18.124 ;$ CA $24=18.517 ;$ RA $12=17.017$. Nitrogen content (\%): Hydrochoric casein: 13.856; Rapeseed concentrate: 8.192. ' Supply per kg of diet: dicalcium phosphate, $10 \mathrm{~g}$; sea salt, $3 \mathrm{~g}$; potassium chloride, $4 \mathrm{~g}$; magnesium carbonate, $2 \mathrm{~g}$; iron sulphate, $500 \mathrm{mg}$; manganese sulphate, $160 \mathrm{mg}$; copper sulphate, 40 $\mathrm{mg}$; zinc sulphate, $440 \mathrm{mg}$; potassium iodide, $450 \mu \mathrm{g}$; sodium selenite, $600 \mu \mathrm{g} .{ }^{2}$ Supply per $\mathrm{kg}$ of diet: vitamin A, $5000 \mathrm{lU}$; vitarnin $\mathrm{D}_{3} 1000 \mathrm{IU}$; tocopherol acetate, $22 \mathrm{mg}$; menadione, $44 \mathrm{mg}$; HCl thiamin, $3.3 \mathrm{mg}$; riboflavin, $6 \mathrm{mg}$; niacin, $36 \mathrm{mg}$; calcium pantothenate, $30 \mathrm{mg}$; $\mathrm{HCl}$ pyridoxine, $3 \mathrm{mg}$; folic acid, $2 \mathrm{mg}$; inositol, $200 \mathrm{mg}$; paraminobenzoic acid, $20 \mathrm{mg}$; biotin, $300 \mu \mathrm{g}$; vitamin $\mathrm{B}_{12}, 30 \mu \mathrm{g}$; choline concentrate, $6 \mathrm{~g}$. 
Table II. Level of amino acid intake $(\mathrm{mg})$ from each test meal.

\section{CA 12 CA $24 \quad$ RA 12}

\begin{tabular}{lrrr}
\hline & & & \\
Val & 7368 & 14376 & 6176 \\
Leu & 10224 & 20168 & 8384 \\
lle & 5768 & 11224 & 4704 \\
Thr & 4160 & 8400 & 4544 \\
Phe & 5376 & 10248 & 4544 \\
Lys & 8664 & 16872 & 7312 \\
Met & 3192 & 6040 & 2744 \\
His & 3176 & 6112 & 3264 \\
Arg & 3864 & 7432 & 6824 \\
Tyr & 5528 & 10864 & 3264 \\
Cys & 704 & 1176 & 3232 \\
Asx & 7752 & 15176 & 7824 \\
Glx & 23312 & 45800 & 20160 \\
Ala & 3312 & 6576 & 5048 \\
Gly & 2184 & 4096 & 6136 \\
Pro & 10312 & 19496 & 6328 \\
Ser & 5304 & 10784 & 4360 \\
& & & \\
S essential aa & 51792 & 100872 & 48496 \\
S non essential aa & 58408 & 113968 & 56352 \\
S total aa & 110200 & 214840 & 104848 \\
\hline
\end{tabular}

$-80^{\circ}$ until the assay performed within 3 months after the experiment. Insulin was measured with a commercial assay system (CEA, France; Sorin Biomedica, Spa, Italy), glucagon with another commercial system (Novopharmaceutic, Copenhagen, Denmark) and gastrin according to Christiansen and Jensen (1980). Blood concentration values of insulin, glucagon and gastrin were calculated taking into account the hematocrit measurements which were carried out throughout the 12-h observation period. The remaining $\mathrm{ml}$ of each blood sample was collected for amino acid analysis in a tube containing 2.75 $\mathrm{ml}$ of a solution of dihydrosulphosalicylic acid $(64.7 \mathrm{~g} / \mathrm{l})$ and thiodiglycol $(6 \mathrm{ml} / \mathrm{l})$. This treatment ensured the breaking of erythrocytes and blood deproteinization prior to the measurement of both intracellular and extracellular circulating free amino acids. The tubes were stirred and stored at $-80^{\circ}$. Free amino acids were extracted by ultrasonic grinding 3 times for $1 \mathrm{~min}$, at discontinuous pulses followed by centrifugation (6 $000 \mathrm{~g}, 20 \mathrm{~min}$ ), collection of the supernatant and adjustment to $\mathrm{pH} 2.2$. The determination of amino acids was made by ion-exchange chromatography in a Beckman 6300 amino acid analyser (Beckman, Palo Alto, CA).

\section{Calculations}

The determination of absorbed quantities (AQ) or produced hormone quantities (HQ), hepatic input $(\mathrm{HI})$, hepatic output $(\mathrm{HO})$, hepatic balance (HB) and hepatic extraction coefficient (HEC) were calculated by the formulae (Rérat et al, 1980; Simoes Nunes et al, 1989) :

$$
\begin{aligned}
& A Q \text { or } H Q=(C p-C a) \times D p ; \\
& H I=(C p \times D p)+(C a \times D a h) \\
& H O=C h \times(D p+D a h) ; \\
& H B=H I-H O ; \\
& H E C=(H I-H O H I) \times 100 ;
\end{aligned}
$$

where $C p$ is the portal concentration, $D p$ the flow in the portal vein, $\mathrm{Ca}$ the arterial concentration, Dah the flow in the hepatic artery and $C h$ the hepatic vein concentration.

Statistical analysis (Snedecor and Cochran, 1967) involved calculation of the mean and standard error of the mean as well as an analysis of variance followed by a Duncan's Multiple Range test. These calculations were performed with the Statistical Analysis System (SAS Institute, Cary, $\mathrm{NC)}$.

\section{RESULTS}

\section{Amino acids absorption}

The absorbed quantities of total amino acids after ingestion of diet CA 24 were $\approx 2$ fold higher than those absorbed after ingestion of the other 2 diets (table III). After $12 \mathrm{~h}$, these quantities represented for all diets approximately the sum of ingested individual amino acids. The absorption profile was similar for the 3 diets with a maxi- 
Table III. Hourly means of absorbed quantities (mg) of amino acids (aa) and $12 \mathrm{~h}$-absorption percentages (\%) in pigs after ingestion of diets CA 12, CA 24 and RA 12.
CA 12
CA 24
RA 12

\begin{tabular}{lccc}
\hline & & & \\
Essential aa mg/h & $4448 \pm 508^{1 \mathrm{a}}$ & $8644 \pm 502^{\mathrm{b}}$ & $4190 \pm 336^{\mathrm{a}}$ \\
Total aa mg/h & $9048 \pm 1188^{\mathrm{a}}$ & $18241 \pm 1222^{\mathrm{b}}$ & $9057 \pm 1324^{\mathrm{a}}$ \\
Essential aa $\%$ & $103 \pm 12^{2}$ & $103 \pm 6$ & $104 \pm 8$ \\
Total aa $\%$ & $99 \pm 13$ & $102 \pm 7$ & $104 \pm 15$ \\
\hline
\end{tabular}

\footnotetext{
1 Mean \pm SD of the mean of 6 determinations. ${ }^{2}$ Mean $\pm S D$ of the mean of 6 determinations expressed as a pecentage of the ingested quantity, ${ }^{a, b}$ Significantly different at the $1 \%$ level.
}

mum hourly absorption at the 3rd and 4th $h$ after $C A 12$ and $C A 24$ feeding and at the 2 nd and 3rd $h$ after RA 12 feeding. The quantities of individual essential amino acids absorbed after ingestion of CA 24 were significantly larger than those absorbed after CA 12 and RA 12 except for Met (table IV). There was no significant difference between the quantities of essential amino acids absorbed after ingestion of diets CA 12 and RA 12. It was the same for the absorption percentages noted for the 3 diets. However, high absorption percentages were noted for His after diets CA 12 and RA 12, for Lys after CA 12 and for Thr after RA 12. The absorbed quantities of non essential amino acids are shown in table $V$. No significant difference appeared between the 3 diets for absorption of Cys, Asp, Glu, Gly, P-Ser, Tau and Orn. The absorbed quantities of the other non essential amino acids appeared significantly higher after CA 24 than after CA 12 and RA 12. Gln showed a negative absorption after CA 12 and RA 12 and slightly positive after CA 24. The absorption percentages of Asp and Glu appeared to be very low. in contrast, those of Ala and Gly appeared to be very high. The absorption percentages of Ala, Gly and Cys were significantly high- er after ingestion of casein diets and that of Pro after protein feeding.

\section{Hepatic amino acid input}

The quantity of amino acids entering the liver after ingestion of diet CA 24 was $\approx$ $10 \%$ higher than that measured after diet CA 12 (table VI). The latter represented $120 \%$ of the flux of amino acids entering the liver in animals fed diet RA 12. Whatever the diet, the essential amino acids accounted for $\approx 40 \%$ of the mixture of total amino acids entering the liver. The quantities of Val, Leu, Thr, Phe, His and Pro entering the liver after ingestion of diet CA 24 were significantly higher than those noted after ingestion of the other 2 diets.

\section{Hepatic amino acid uptake}

The quantities of essential and total amino acids taken up by the liver after ingestion of CA 24 were significantly higher than those taken up after CA 12 and RA 12. This was true in term of real amounts of amino acids as well as in percentage of 
Table IV. Hourly means of the absorbed quantities $(\mathrm{mg})$ of essential amino acids and $12 \mathrm{~h}$-absorption percentages (\%) in pigs after ingestion of diets CA 12, CA 24 and RA 12.

\begin{tabular}{|c|c|c|c|c|}
\hline & & CA 12 & $C A 24$ & $R A 12$ \\
\hline Val & $\begin{array}{l}\mathrm{mg} / \mathrm{h} \\
(\%)\end{array}$ & $\begin{array}{c}590 \pm 125^{1, c} \\
96 \pm 20^{2}\end{array}$ & $\begin{array}{c}1257 \pm 178^{d} \\
105 \pm 15\end{array}$ & $\begin{array}{l}594 \pm 122^{c} \\
115 \pm 24\end{array}$ \\
\hline Leu & & $\begin{array}{c}764 \pm 157^{e} \\
90 \pm 18\end{array}$ & $\begin{array}{c}1719 \pm 173^{\prime} \\
102 \pm 10\end{array}$ & $\begin{array}{c}628 \pm 80^{\circ} \\
90 \pm 11\end{array}$ \\
\hline Ile & & $\begin{array}{c}452 \pm 117^{e} \\
94 \pm 24\end{array}$ & $\begin{array}{c}925 \pm 78^{f} \\
99 \pm 8\end{array}$ & $\begin{array}{c}355 \pm 44^{\theta} \\
91 \pm 11\end{array}$ \\
\hline Thr & & $\begin{array}{l}350 \pm 103^{a} \\
101 \pm 30\end{array}$ & $\begin{array}{c}677 \pm 89^{b} \\
97 \pm 13\end{array}$ & $\begin{array}{l}486 \pm 70^{a} \\
128 \pm 18\end{array}$ \\
\hline Phe & & $\begin{array}{c}427 \pm 88^{\circ} \\
95 \pm 20\end{array}$ & $\begin{array}{l}942 \pm 86^{\dagger} \\
110 \pm 10\end{array}$ & $\begin{array}{c}339 \pm 47^{\circ} \\
90 \pm 12\end{array}$ \\
\hline Lys & & $\begin{array}{l}866 \pm 187^{c} \\
120 \pm 26\end{array}$ & $\begin{array}{c}1473 \pm 165^{d} \\
105 \pm 12\end{array}$ & $\begin{array}{l}661 \pm 127^{c} \\
108 \pm 21\end{array}$ \\
\hline Met & & $\begin{array}{r}245 \pm 84 \\
92 \pm 32\end{array}$ & $\begin{array}{r}446 \pm 122 \\
89 \pm 24\end{array}$ & $\begin{array}{r}215 \pm 43 \\
94 \pm 19\end{array}$ \\
\hline His & & $\begin{array}{l}379 \pm 77^{a b} \\
143 \pm 29\end{array}$ & $\begin{array}{c}488 \pm 48^{b} \\
96 \pm 9\end{array}$ & $\begin{array}{l}369 \pm 41^{a} \\
136 \pm 15\end{array}$ \\
\hline Arg & & $\begin{array}{l}375 \pm 77^{a} \\
116 \pm 24\end{array}$ & $\begin{array}{l}717 \pm 64^{b} \\
115 \pm 10\end{array}$ & $\begin{array}{c}543 \pm 97^{\mathrm{ab}} \\
95 \pm 17\end{array}$ \\
\hline
\end{tabular}

${ }^{1}$ Mean \pm SD of the mean of 6 determinations. ${ }^{2}$ Mean \pm SD of the mean of 6 determinations expressed as a percentage of the ingested quantity. $a, b$ Significantly different at the $5 \%$ level. $c, d$ Significantly different at the $1 \%$ level. e,f Significantly different at the $1 \%$ level.

the absorbed quantities of amino acids (table VII). Within the mixture of amino acids taken up by the liver, the essential amino acids represented 138,48 and $75 \%$ respectively of the mixture of total amino acids for CA 12, CA 24 and RA 12. Among the essential amino acids, the quantities of Val, Thr, Phe, Lys and His retained by the liver were significantly higher after intake of CA 24 than after CA 12 and RA 12 (table VIII). There was a negative hepatic uptake (liver output exceeding liver input) of $\mathrm{Val}$ after ingestion of RA 12. The quantity of Arg retained by the hepatic parenchy- ma after diet RA 12 was significantly higher than after CA 12.

The kinetic profile of the hepatic uptake of essential amino acids showed marked differences according to ingested diets. The hepatic balance of each essential amino acid was always positive after ingestion of CA 24 with the exception of Met, the hepatic balance of which was negative during the last $2 \mathrm{~h}$ of observation. After intake of CA 12, the hepatic balance was always positive for Leu, lle and Phe. It was alternately positive and negative for $\mathrm{Val}$, Thr, Lys, Met and His. That of Arg was positive 
Table V. Hourly means of absorbed quantities $(\mathrm{mg})$ of non essential amino acids and $12 \mathrm{~h}$-absorption percentages (\%) in pigs after ingestion of diets CA 12, CA 24 and RA 12.

\begin{tabular}{|c|c|c|c|c|}
\hline & & $C A 12$ & $C A 24$ & $R A 12$ \\
\hline Tyr & $\begin{array}{c}\mathrm{mg} / \mathrm{h} \\
(\%)\end{array}$ & $\begin{array}{l}502 \pm 84^{t, \theta} \\
109 \pm 18^{2}\end{array}$ & $\begin{array}{c}1055 \pm 134^{\prime} \\
117 \pm \quad 15\end{array}$ & $\begin{array}{l}271 \pm 58^{\theta} \\
100 \pm 21\end{array}$ \\
\hline Cys & & $\begin{array}{c}82 \pm 14 \\
140 \pm 24^{a}\end{array}$ & $\begin{array}{l}137 \pm 48 \\
140 \pm 49^{a}\end{array}$ & $\begin{array}{lc}87 \pm & 19 \\
32 \pm & 7 b\end{array}$ \\
\hline Asp & & $257 \pm 81$ & $363 \pm 117$ & $267 \pm 41$ \\
\hline Asn & & $799 \pm 166^{\ominus}$ & $1906 \pm 184^{t}$ & $928 \pm 171^{\theta}$ \\
\hline Glu & & $363 \pm 102$ & $331 \pm 69$ & $487 \pm 275$ \\
\hline Gin & & $-660 \pm 171^{a}$ & $9 \pm 273^{b}$ & $-258 \pm 237^{a b}$ \\
\hline Ala & & $\begin{array}{r}1020 \pm 143^{c} \\
370 \pm 52^{a}\end{array}$ & $\begin{array}{c}1666 \pm 104^{d} \\
304 \pm 19^{a}\end{array}$ & $\begin{array}{l}863 \pm 223^{c} \\
205 \pm 53^{b}\end{array}$ \\
\hline Gly & & $\begin{array}{l}424 \pm 116 \\
233 \pm 64^{a}\end{array}$ & $\begin{array}{l}602 \pm 41 \\
247 \pm 12^{a}\end{array}$ & $\begin{array}{ll}655 \pm 85 \\
128 \pm 17^{b}\end{array}$ \\
\hline Pro & & $\begin{array}{r}753 \pm 123^{a} \\
88 \pm 14^{a}\end{array}$ & $\begin{array}{r}1555 \pm 191^{b} \\
96 \pm 12^{a}\end{array}$ & $\begin{array}{l}984 \pm 294^{a} \\
187 \pm 56^{b}\end{array}$ \\
\hline Ser & & $\begin{array}{l}467 \pm 117^{\ominus} \\
106 \pm 26\end{array}$ & $\begin{array}{c}1082 \pm 82^{f} \\
120 \pm 9\end{array}$ & $\begin{array}{l}407 \pm 106^{\ominus} \\
112 \pm 29\end{array}$ \\
\hline P-Ser & & $38 \pm 8$ & $61 \pm 15$ & $52 \pm 13$ \\
\hline Tau & & $5 \pm 138$ & $1 \pm 40$ & $-361 \pm 353$ \\
\hline Orn & & $231 \pm 35$ & $290 \pm 76$ & $201 \pm 37$ \\
\hline Cit & & $319 \pm 62^{a}$ & $539 \pm 66^{b}$ & $284 \pm 65^{a}$ \\
\hline
\end{tabular}

${ }^{1}$ Mean \pm SD of the mean of 6 determinations. ${ }^{2}$ Mean $\pm S D$ of the mean of 6 determinations expressed as a percentage of the ingested quantity. a,b Significantly different at the 5\% level. c,d Significantly different at the $1 \%$ level. e.l Significantly different at the $1 \%$ level.

during the first $10 \mathrm{~h}$ and negative thereafter. During the RA 12 post-feeding period, the hepatic balance of Val, Met and His showed the same profiles as those noted after the intake of CA 12. Those of Leu, lle, Phe, Lys and Arg were always positive except during the last $h$ of observation. The hepatic balance of Thr was positive during the first $10 \mathrm{~h}$ after feeding and negative during the last $2 h$ of observation.
The hepatic extraction coefficient of essential amino acids was higher for almost all individual essential amino acids after ingestion of CA 24 than after those of CA 12 and RA 12. These differences were significant for Val, Phe, Lys, His and Arg.

Taking into account the differences observed in the hepatic uptake of essential amino acids, the non hepatic tissues received and utilized different proportions of 
Table VI. Hourly means $(\mathrm{g})$ of hepatic input fluxes of amino acids in pigs after ingestion of diets CA 12, CA 24 and RA 12.

\begin{tabular}{lccc}
\hline & $C A 12$ & $C A 24$ & $R A 12$ \\
\hline Val & & & \\
Leu & $5.95 \pm 0.70^{1, c}$ & $10.83 \pm 0.60^{\mathrm{d}}$ & $7.37 \pm 0.30^{\mathrm{c}}$ \\
Ile & $3.78 \pm 0.53^{\mathrm{a}}$ & $7.38 \pm 0.56^{\mathrm{f}}$ & $3.57 \pm 0.159$ \\
Thr & $4.34 \pm 0.69^{\mathrm{a}}$ & $4.38 \pm 0.21^{\mathrm{a}}$ & $2.99 \pm 0.26^{\mathrm{b}}$ \\
Phe & $6.03 \pm 0.44^{\mathrm{b}}$ & $3.88 \pm 0.30^{\mathrm{a}}$ \\
Lys & $10.58 \pm 0.14^{\mathrm{a}}$ & $3.63 \pm 0.35^{\mathrm{f}}$ & $2.15 \pm 0.13^{\mathrm{\theta}}$ \\
Met & $1.39 \pm 0.95^{\mathrm{c}}$ & $11.19 \pm 0.52^{\mathrm{c}}$ & $7.68 \pm 0.48^{\mathrm{d}}$ \\
His & $2.67 \pm 0.12^{\mathrm{a}}$ & $2.27 \pm 0.56$ & $1.32 \pm 0.08$ \\
Arg & $3.04 \pm 0.24$ & $3.13 \pm 0.15^{\mathrm{b}}$ & $2.57 \pm 0.13^{\mathrm{a}}$ \\
Tyr & $4.15 \pm 0.49^{\mathrm{a}}$ & $5.40 \pm 0.34$ & $3.72 \pm 0.27$ \\
Cys & $1.20 \pm 0.20$ & $1.36 \pm 0.24$ & $2.37 \pm 0.28^{\mathrm{b}}$ \\
Asp & $1.28 \pm 0.16$ & $1.23 \pm 0.22$ & $1.32 \pm 0.22$ \\
Asn & $5.81 \pm 1.44$ & $6.77 \pm 0.66$ & $1.02 \pm 0.14$ \\
Glu & $6.44 \pm 0.38$ & $4.83 \pm 0.63$ & $5.97 \pm 0.99$ \\
Gln & $7.98 \pm 0.70$ & $7.98 \pm 1.23$ & $6.93 \pm 0.43$ \\
Ala & $5.93 \pm 0.71$ & $4.74 \pm 0.25$ & $5.22 \pm 0.62$ \\
Gly & $10.59 \pm 1.40$ & $9.02 \pm 0.74$ & $9.72 \pm 0.82$ \\
Pro & $8.76 \pm 1.14^{\mathrm{a}}$ & $11.94 \pm 0.76^{\mathrm{b}}$ & $6.02 \pm 0.50^{\mathrm{a}}$ \\
Ser & $2.85 \pm 0.36$ & $3.31 \pm 0.21$ & $2.30 \pm 0.12$ \\
P-Ser & $1.10 \pm 0.14$ & $1.09 \pm 0.08$ & $1.09 \pm 0.10$ \\
Tau & $8.96 \pm 1.02$ & $8.57 \pm 0.78$ & $6.97 \pm 0.58$ \\
Orn & $4.18 \pm 0.35$ & $4.20 \pm 0.28$ & $4.07 \pm 0.36$ \\
Cit & $3.03 \pm 0.28$ & $3.43 \pm 0.34$ & $2.72 \pm 0.15$ \\
& & & \\
\hline & & & \\
\hline & & & \\
\hline
\end{tabular}

${ }^{1}$ Mean \pm SD of the mean of 6 determinations. a. o Significantly different at the $5 \%$ level. c, d Significantly different at the $1 \%$ level. $0.1,9$ Significantly different at the $1 \%$ o level.

absorbed essential amino acids. Thus the fraction of essential amino acids taken up in the free form by the non hepatic tissues accounted for 64,33 and $60 \%$ respectively of the absorbed mixture after ingestion of CA 12, CA 24 and RA 12. Among the essential amino acids, Phe showed the lowest non hepatic tissue uptake (32 and $25 \%$ ) and $\mathrm{Val}$ the highest (92 and $104 \%$ ) after ingestion of CA 12 and RA 12 respectively. In the case of CA 24, the 2 amino acids showing the extreme values for non hepatic tissue uptake were Phe $(11 \%)$ and Met (72\%).
The quantity of amino acids leaving the liver after intake of CA 24 was only $3 \%$ higher than that measured after CA 12. This small difference was due to a proportionally higher hepatic amino acid uptake after ingestion of CA 24 than after that of CA 12. The hepatic output of amino acids after intake of CA 12 accounted for $119 \%$ of that observed in animals fed diet RA 12. Inside the amino acid mixture leaving the liver, the essential amino acids accounted for $36 \%$ of the sum of amino acids after ingestion of CA 12 and RA 12; after that of CA 24, they accounted for $41 \%$. 
Table VII. Hourly means (mg) of the quantities of amino acids (aa) taken up by the liver and percentage (\%) of absorbed amino acids taken up by the liver in $12 \mathrm{~h}$ in pigs after ingestion of diets CA 12 , CA 24 and RA 12.
CA 12
CA 24
CA 12

$\begin{array}{lcrr}\text { Essential aa mg/h } & 1591 \pm 562^{1, a} & 5814 \pm 842^{\mathrm{b}} & 1689 \pm 365^{\mathrm{a}} \\ \text { Total aa mg/h } & 1149 \pm 745^{\mathrm{a}} & 12072 \pm 2057^{\mathrm{b}} & 2240 \pm 624^{\mathrm{a}} \\ \text { Essential aa \% } & 36 \pm 13^{2, \mathrm{a}} & 67 \pm 10^{\mathrm{b}} & 40 \pm 9^{\mathrm{a}} \\ \text { Total aa \% } & 13 \pm 8^{\mathrm{a}} & 66 \pm 11^{\mathrm{b}} & 25 \pm 7^{\mathrm{a}}\end{array}$
${ }^{1}$ Mean \pm SD of the mean of 6 determinations. ${ }^{2}$ Mean \pm SD of the mean of 6 determinations expressed as a percen-
tage of the absorbed quantity, a, b Significantly different at the $1 \%$ level.

The hepatic uptake of non essential amino acids after intake of CA 24 feeding was generally higher than that measured for the other 2 diets (table IX). Nevertheless, the individual differences were not significant for Asp, Gly, Pro, P-Ser, Tau and Orn. The hepatic balances of Asp and Glu were negative after all 3 diets, but the hepatic production of Glu was much smaller after ingestion of CA 24 than after that of the other 2 diets. There were negative balances of Cys and Tau after intake of CA 12 and RA 12. It was the same for Orn after RA 12 feeding.

Kinetic profiles of hepatic uptake of Ala, Gly, Pro and Ser were always positive and very similar for all the 3 diets. Those of Asp and Glu were always negative and similar for the 3 dietary treatments. In the profiles of hepatic uptake of Asn, P-Ser, Tau, Cit and Orn alternating phases of positive and negative balance were noted after intake of all the 3 diets. After CA 12 and RA 12 feeding the phases of hepatic output of Tau were larger than those of hepatic uptake. That was also the case for Orn after ingestion of diet RA 12. Finally, the kinetic profile of hepatic GIn balance was always positive after CA 24 treatment; positive during the first $10 \mathrm{~h}$ of the obser- vation period and negative thereafter following ingestion of diet RA 12 and always negative with the exception of the 2nd and 4th $h$ after CA 12 feeding.

The hepatic coefficients of extraction of non essential amino acids are shown in table IX. These coefficients were significantly higher after ingestion of CA 24 for Tyr, Asn, Gln, Ala, Ser and Cit than after that of the other 2 diets. The hepatic extraction coefficients of Asp and Glu were negative for all 3 diets and lower in absolute values after intake of CA 24 (non significant differences). The hepatic extraction coefficient of Pro was higher after RA 12 feeding.

The fraction of non essential amino acids taken up by the non hepatic tissues represented 110,35 and $89 \%$ respectively of the absorbed mixture of non essential amino acids after CA 12, CA 24 and RA 12 feeding.

\section{Insulin, glucagon and gastrin}

The lowest mean production of insulin was observed after ingestion of diet RA 12 (table X). This production represented only $72 \%$ of that noted after ingestion of the 2 
Table VIll. Hourly means (mg) of the quantities of essential amino acids taken up by the liver (HB) and mean hepatic extraction coefficients (HEC) in pigs after ingestion of diets CA 12, CA 24 and RA 12.

\begin{tabular}{|c|c|c|c|c|}
\hline & & $C A 12$ & $C A 24$ & $R A 12$ \\
\hline Val & $\begin{array}{l}\mathrm{HB}(\mathrm{mg}) \\
\mathrm{HEC}(\%)\end{array}$ & $\begin{array}{c}48 \pm 173^{1, a} \\
1 \pm \quad 2^{\mathrm{a}}\end{array}$ & $\begin{array}{c}927 \pm 410^{\mathrm{b}} \\
9 \pm \quad 4^{\mathrm{b}}\end{array}$ & $\begin{array}{l}-22 \pm 54^{a} \\
-0.2 \pm 0.7^{a}\end{array}$ \\
\hline Leu & & $\begin{array}{r}349 \pm 162 \\
6 \pm \quad 3\end{array}$ & $\begin{array}{c}909 \pm 324 \\
12 \pm 4\end{array}$ & $\begin{array}{r}297 \pm 110 \\
8 \pm 3\end{array}$ \\
\hline lle & & $\begin{array}{r}215 \pm 109 \\
6 \pm \quad 3\end{array}$ & $\begin{array}{c}502 \pm 167 \\
11 \pm \quad 4\end{array}$ & $\begin{array}{rr}193 \pm & 80 \\
6 \pm & 3\end{array}$ \\
\hline Thr & & $\begin{array}{c}141 \pm 118^{a} \\
3 \pm 3\end{array}$ & $\begin{array}{c}513 \pm 120^{b} \\
9 \pm \quad 2\end{array}$ & $\begin{array}{c}165 \pm 104^{a} \\
4 \pm \quad 3\end{array}$ \\
\hline Phe & & $\begin{array}{r}290 \pm 109^{e} \\
11 \pm \quad 4^{a}\end{array}$ & $\begin{array}{c}839 \pm 111^{f} \\
23 \pm 3^{b}\end{array}$ & $\begin{array}{r}255 \pm 90^{e} \\
12 \pm 3^{a}\end{array}$ \\
\hline Lys & & $\begin{array}{c}239 \pm 206^{\mathrm{c}} \\
2 \pm \quad 2^{\mathrm{a}}\end{array}$ & $\begin{array}{r}1181 \pm 255^{d} \\
11 \pm \quad 2^{b}\end{array}$ & $\begin{array}{c}310 \pm 122^{c} \\
4 \pm \quad 2^{a}\end{array}$ \\
\hline Met & & $\begin{array}{r}101 \pm 77 \\
7 \pm 6\end{array}$ & $\begin{array}{rr}127 \pm 92 \\
6 \pm & 4\end{array}$ & $\begin{array}{r}57 \pm 39 \\
4 \pm 3\end{array}$ \\
\hline His & & $\begin{array}{r}104 \pm 85^{a} \\
4 \pm 3^{a}\end{array}$ & $\begin{array}{r}354 \pm 64^{\mathrm{b}} \\
11 \pm 2^{\mathrm{b}}\end{array}$ & $\begin{array}{r}110 \pm 70^{a} \\
4 \pm 3^{a}\end{array}$ \\
\hline Arg & & $\begin{array}{r}104 \pm 85^{\mathrm{a}} \\
3 \pm 3^{\mathrm{a}}\end{array}$ & $\begin{array}{r}462 \pm 141^{b} \\
13 \pm 4^{b}\end{array}$ & $\begin{array}{c}324 \pm 92^{b} \\
9 \pm 2^{a b}\end{array}$ \\
\hline
\end{tabular}

1 Mean \pm SD of the mean of 6 determinations. a, b Significantly different at the $5 \%$ level. c, d Significantly different at the $1 \%$ level. ${ }^{e}$, Significantly different at the $1 \%$ o level.

casein diets. After intake of diet CA 12 the insulin production was high until the 8 th $h$ of observation. After CA 24 feeding the highest insulin production was seen during the first $6 \mathrm{~h}$ following the meal whilst after intake of RA 12 insulin production decreased regularly until the 7 th $h$ following the meal and steadily afterwards. The highest liver input fluxes of insulin were observed after ingestion of diets CA 12 and CA 24 as well as the highest balances of the hormone. The kinetic profiles of hepatic uptake of insulin reflected those of the production. The hepatic extraction co- efficients of the produced insulin and of the hormone exposed to the liver appeared to be very similar for all 3 diets (table $X$ ).

No significant difference between the 3 diets appeared concerning the productions, kinetic profiles of productions, liver input fluxes and hepatic extraction coefficients of glucagon and gastrin.

Taking into account the observed differences in the production of insulin, the insulin/glucagon ratio in the 3 analysed types of blood (portal, hepatic and arterial) was always lower after intake of the rapeseed concentrate diet. 
Table IX. Hourly means (mg) of the quantities of non essential amino acids taken up by the liver (HB) and mean hepatic extraction coefficients (HEC) in pigs after the ingestion of diets CA 12, CA 24 and RA 12.

\begin{tabular}{|c|c|c|c|c|}
\hline & & $C A 12$ & $C A 24$ & $R A 12$ \\
\hline Tyr & $\begin{array}{l}\mathrm{HB} \text { mg/h } \\
\mathrm{HEC} \%\end{array}$ & $\begin{array}{cc}372 \pm & 90^{1, \theta} \\
9 \pm & 2^{\mathrm{a}}\end{array}$ & $\begin{array}{c}958 \pm 117^{f} \\
18 \pm \quad 2^{b}\end{array}$ & $\begin{array}{rr}192 \pm & 48^{\mathrm{e}} \\
8 \pm & 2^{\mathrm{a}}\end{array}$ \\
\hline Cys & & $\begin{array}{c}-38 \pm 16^{a} \\
-3 \pm 1\end{array}$ & $\begin{array}{c}42 \pm 31 b \\
3 \pm 2\end{array}$ & $\begin{array}{cc}-88 \pm & 50^{a} \\
-6 \pm & 4\end{array}$ \\
\hline Asp & & $\begin{array}{r}-384 \pm 108 \\
-30 \pm 8\end{array}$ & $\begin{array}{r}-259 \pm 178 \\
-21 \pm 14\end{array}$ & $\begin{array}{r}-258 \pm 112 \\
-25 \pm 11\end{array}$ \\
\hline Asn & & $\begin{array}{r}173 \pm 138^{c} \\
3 \pm \quad 2^{a}\end{array}$ & $\begin{array}{c}1385 \pm 371^{d} \\
20 \pm 5^{b}\end{array}$ & $\begin{array}{r}433 \pm 123^{c} \\
10 \pm \quad 3^{a}\end{array}$ \\
\hline Glu & & $\begin{array}{c}-2374 \pm 432^{a} \\
-37 \pm \quad 7\end{array}$ & $\begin{array}{c}-1125 \pm 399 b \\
-23 \pm 8\end{array}$ & $\begin{array}{c}-1810 \pm 461^{a b} \\
-31 \pm 7\end{array}$ \\
\hline Gin & & $\begin{array}{c}-148 \pm 210^{c} \\
-2 \pm \quad 3^{a}\end{array}$ & $\begin{array}{c}946 \pm 183 d \\
12 \pm \quad 2^{b}\end{array}$ & $\begin{array}{r}354 \pm 209^{c} \\
5 \pm \quad 3^{a}\end{array}$ \\
\hline Ala & & $\begin{array}{c}890 \pm 181^{a} \\
15 \pm \quad 3^{a}\end{array}$ & $\begin{array}{c}1450 \pm 183^{b} \\
31 \pm \quad 4^{b}\end{array}$ & $\begin{array}{r}648 \pm 319^{a} \\
12 \pm \quad 6^{a}\end{array}$ \\
\hline Gly & & $\begin{array}{rr}329 \pm 67 \\
3 \pm 1\end{array}$ & $\begin{array}{rr}514 \pm & 81 \\
6 \pm & 1\end{array}$ & $\begin{array}{r}294 \pm 154 \\
3 \pm \quad 2\end{array}$ \\
\hline Pro & & $\begin{array}{l}307 \pm 161 \\
4 \pm \quad 2^{a}\end{array}$ & $\begin{array}{c}750 \pm 349 \\
6 \pm \quad 3^{\mathrm{ab}}\end{array}$ & $\begin{array}{c}794 \pm 325 \\
13 \pm 5^{b}\end{array}$ \\
\hline Ser & & $\begin{array}{r}248 \pm 111^{c} \\
9 \pm \quad 4^{a}\end{array}$ & $\begin{array}{r}806 \pm 152^{d} \\
24 \pm \quad 5^{b}\end{array}$ & $\begin{array}{r}313 \pm 126^{\mathrm{c}} \\
14 \pm \quad 5^{\mathrm{ab}}\end{array}$ \\
\hline P-Ser & & $\begin{array}{rr}31 \pm & 10 \\
3 \pm & 1\end{array}$ & $\begin{array}{rr}67 \pm & 43 \\
6 \pm & 4\end{array}$ & $\begin{array}{rr}35 \pm & 11 \\
3 \pm & 1\end{array}$ \\
\hline Tau & & $\begin{array}{r}-53 \pm 126 \\
-1 \pm 1\end{array}$ & $\begin{array}{r}173 \pm 193 \\
2 \pm \quad 2\end{array}$ & $\begin{array}{r}-288 \pm 357 \\
-4 \pm \quad 5\end{array}$ \\
\hline Orn & & $\begin{array}{r}116 \pm 103 \\
3 \pm 2\end{array}$ & $\begin{array}{rr}169 \pm & 46 \\
4 \pm & 1\end{array}$ & $\begin{array}{r}-105 \pm 153 \\
-3 \pm \quad 4\end{array}$ \\
\hline Cit & & $\begin{array}{r}89 \pm 72^{\mathrm{a}} \\
3 \pm \quad 2^{\mathrm{a}}\end{array}$ & $\begin{array}{r}382 \pm 105^{b} \\
11 \pm \quad 3^{b}\end{array}$ & $\begin{array}{c}37 \pm 140^{\mathrm{a}} \\
1 \pm 5^{\mathrm{ab}}\end{array}$ \\
\hline
\end{tabular}

${ }^{1}$ Mean \pm SD of the mean of 6 determinations. ${ }^{a, b}$ Significantly different at the $5 \%$ level. c. d Significantly different at the $1 \%$ level. e. i Significantiy different at the $1 \%$ level. 
Table X. Hourly means of productions $(P)$, hepatic input fluxes $(H E)$, hepatic balances $(H B)$ of insulin $(\mathrm{mU} / \mathrm{h})$, glucagon $(\mathrm{ng} / \mathrm{h})$ and gastrin $(\mathrm{ng} / \mathrm{h}$ ) and mean hepatic extraction coefficients according to the produced quantity of hormone (HEP) or according to the quantity of hormone exposed to the liver (HEC) in pigs after ingestion of diets CA 12, CA 24 and RA 12.

\begin{tabular}{|c|c|c|c|c|}
\hline & & $C A 12$ & $C A 24$ & $R A 12$ \\
\hline Insulin & $\begin{array}{r}P \\
H E \\
H B \\
H E P \\
\text { HEC }\end{array}$ & $\begin{array}{c}2735 \pm 270^{1, a} \\
6361 \pm 379^{a} \\
1656 \pm 200^{a} \\
54 \pm 10 \\
21 \pm 7\end{array}$ & $\begin{array}{r}2723 \pm 230^{a} \\
6071 \pm 273^{a} \\
1569 \pm 190^{a} \\
58 \pm 9 \\
25 \pm 5\end{array}$ & $\begin{array}{c}1972 \pm 220^{\mathrm{b}} \\
4876 \pm 345^{\mathrm{b}} \\
1146 \pm 150^{\mathrm{b}} \\
58 \pm 3 \\
24 \pm \quad 2\end{array}$ \\
\hline Glucagon & $\begin{array}{r}P \\
H E \\
H B \\
H E P \\
H E C\end{array}$ & $\begin{array}{rr}24938 \pm 5875 \\
115516 \pm 13517 \\
12849 \pm 3867 \\
52 \pm & 5 \\
11 \pm & 1\end{array}$ & $\begin{array}{rr}28800 \pm & 5712 \\
126898 \pm 12058 \\
11566 \pm 6468 \\
40 \pm & 1 \\
8 \pm & 3\end{array}$ & 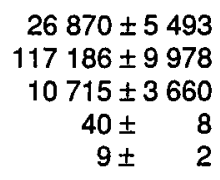 \\
\hline Gastrin & $\begin{array}{r}P \\
H E \\
H B \\
H E P \\
\text { HEC }\end{array}$ & $\begin{array}{r}1165 \pm 259 \\
4020 \pm 489 \\
422 \pm 167 \\
36 \pm 6 \\
10 \pm 2\end{array}$ & $\begin{array}{r}1136 \pm 251 \\
4165 \pm 337 \\
483 \pm 166 \\
43 \pm 6 \\
12 \pm \quad 2\end{array}$ & $\begin{array}{r}1142 \pm 212 \\
4301 \pm 365 \\
432 \pm 181 \\
38 \pm 7 \\
10 \pm \quad 3\end{array}$ \\
\hline
\end{tabular}

${ }^{1}$ Mean \pm SD of the mean of 6 determinations. a, b Significantly different at the $5 \%$ level.

\section{DISCUSSION AND CONCLUSION}

Blood plasma is the main interorgan vehicle of most amino acids. Nevertheless, some amino acids such as Glu, Gln, Asp and Tau are found in higher concentrations in the red cells than in the blood plas$\mathrm{ma}$ and thus can participate in intertissue amino acid transfers (Elwyn et al, 1972). This was the reason why we used the measurement of free amino acids in whole blood. A good amino acid absorption balance was observed after ingestion of the casein based diets. This finding was largely expected since casein is a good quality protein. More surprising was the absorption balance of total amino acids measured after rapeseed concentrate feeding which appeared particularly high for a plant protein especially when considering what was observed with cereal proteins (Rérat et al, 1979). The absorption percentages noted $12 \mathrm{~h}$ after the test meals suggest an optimum uptake and transport of oligopeptides and amino acids resulting from the intraluminal digestive hydrolysis of dietary and endogenous proteins as well as from those resulting from the metabolism of the gut wall. The absorption percentages were higher than those observed by Galibois et al (1989) $8 \mathrm{~h}$ after intake of similar diets.

Interesting differences between the 2 sources of proteins concerned the balances of individual non essential amino acids appearing in the portal vein. The low absorption coefficients of Asp and Glu as 
well as the high absorption coefficients of Ala and Gly were the result of deamination and transamination reactions in the intestinal wall during the absorptive process (Windmueller and Spaeth, 1980). The intestinal balance of GIn was either slightly positive or negative indicating a large metabolic utilization of this amino acid by the intestinal wall. Cit and Orn were synthesized by the intestinal wall. Cit seemed to originate from the metabolism of Gin, and Orn from that of dietary and blood Arg (Windmueller and Spaeth, 1980). The low appearance of Cit and Orn in the portal blood after ingestion of rapeseed proteins may suggest that the very high apparent absorption coefficient of Pro partially resulted from an increased metabolism of Cit and Orn into Pro in the intestinal wall. The intestinal balance of Tau was close to zero after ingestion of casein based diets and negative after that of rapeseed proteins and the highest hepatic production of Tau was observed in the latter nutritional situation.

The higher amino acid uptake observed after ingestion of diet CA 24 appeared to be the combined result of an increased hepatic input flux of amino acids, a probable induction and higher activity of transport systems as well as an acceleration of hepatocyte metabolism. In the rat Ala hepatic transport and metabolism were increased after ingestion of high-protein diets (Fafournoux et al, 1982, 1983).

Whatever the diet ingested by the animals, Phe, Ala and Ser showed the highest hepatic uptake coefficient. Among the branched chain amino acids, Val showed the lowest hepatic uptake and the highest non hepatic tissue uptake. A low hepatic uptake of branched chain amino acids was also observed in the dog, suggesting a large participation of these amino acids in nitrogen transfers from the liver to the non hepatic tissues (Elwyn, 1970; Bloomgarden et al, 1981; Barrett et al, 1986).
It was of considerable interest that the hepatic extraction level of Met was not modified by the quantity of ingested protein. Hence the quantity of Met reaching and utilized by the non hepatic tissues was larger after ingestion of CA 24 than after that of $\mathrm{Ca}$ 12. Further studies should be made to determine the metabolic behaviour of Met (higher participation in protein synthesis or catabolism).

The very high hepatic productions of Asp and Glu (Gelfand et al, 1986) in the 3 different nutritional situations must be underlined. It appears that a large proportion of Asp and Glu participating in the non hepatic transamination reactions originated from the liver. It also seems that hepatic behaviour of Asp and Glu in the pig is different from that in the dog. During the post-prandial period there is hepatic extraction of both diacids and not a net hepatic production in the latter species as in the pig.

Two of the glucose-forming amino acids, Ala and Ser, showed the highest level of hepatic extraction. This level appeared also to be highly increased by the ingestion of a high casein diet. Both amino acids are carbon sources for glucose synthesis (Kaplan and Pitot, 1970) and the $\mathrm{NH}_{2}$ radicals of Ala participate in the observed high hepatic productions of Glu.

The differences noted in the hepatic extraction level according to the quantity and nature of ingested proteins underline that the liver profoundly modifies the profile of the amino acid mixtures entering the organ. The "buffer" role of the liver in the availability of dietary and endogenous amino acids for the non hepatic tissues can no longer be considered as "uniform", but as being rather selective.

The lowest mean hourly production of insulin was observed after ingestion of rapeseed proteins. The lower glucose ab- 
sorption after intake of this diet (Simoes Nunes et al, 1989) was very likely the main reason for the difference observed between casein and rapeseed diets. Indeed, other amino acids with an insulinotropic effect such as Leu, Lys and Arg were absorbed in equivalent quantities whatever the type of proteins ingested, and cannot be at the origin of the quantitatively lower insulin production noted after ingestion of rapeseed proteins.

The mean hourly glucagon and gastrin productions were very similar for all 3 diets. In the pig, both secretions were higher after the ingestion of protein containing diets than after that of a protein free diet (Rérat et al, 1985). In the present study the effectiveness of the 2 very different proteins to induce release of glucagon and gastrin was very similar.

For all diets the hepatic extraction of insulin ranged between $21-25 \%$ of the hormone exposed to the liver. For glucagon the same extraction ranged between 8$11 \%$ and for gastrin between $10-12 \%$. Thus, independently of the nutritional situation, the level of hepatic extraction of circulating insulin was proportionally much higher than that of glucagon and gastrin. In the dog, the hepatic extraction coefficient of insulin was also much higher than that of glucagon (Röjdmark et al, 1978; Ishida et al, 1983). Further research should be carried out to explain this particular hepatic behaviour of insulin.

\section{ACKNOWLEDGMENTS}

The authors thank S Guérin, $G$ Brachet and $F$ Cointepas for skillful technical assistance. This work was supported by grants from Programme France-Québec sur les Biotechnolgies and CNIEL-CIDIL.

\section{REFERENCES}

Barrett EJ, Gusberg R, Ferrannini E, Tepler J, Felig $P$, Jacob $P$, Smith D, De Fronzo RA (1986) Amino acid and glucose metabolism in the postabsorptive state and following amino acid ingestion in the dog. Metabolism 35, 709-717

Bergman EN, Heitmann RN (1978) Metabolism of amino acids by the gut, liver, kidneys and peripheral tissues. Fed Proc 37, 1228-1232

Bloomgarden ZT, Liljenquist J, Lacy W, Rabin D (1981) Amino acid disposition by the liver and gastrointestinal tract after protein and glucose ingestion. $A m J$ Physiol 241, E90E99

Cherrington $A D$, Williams $P E$, Abou-Mourad $M$, Lacy WW, Steiner KE, Liljenquist JE (1982) Insulin as a mediator of hepatic glucose uptake in the conscious dog. Am J Physiol 242, E97-E101

Christiansen LA, Jensen SL (1980) Gastrin release in pigs during intestinal pouch stimulation with meal extract. Scand J Gastroenterol $15,577-580$

Elwyn DH (1970) The role of the liver in regulation of amino acid and protein metabolism. In: Mammalian Protein Metabolism IV (Munro HN, ed) Academic Press, New York, 523-557

Elwyn DH, Parikh HC, Shoemaker WC (1968) Amino acid movements between gut, liver and periphery in unanesthetized dogs. $J$ Physiol 215, 1260-1275

Elwyn DH, Launder WJ, Parikh HC, Wise EM (1972) Roles of plasma and erythrocytes in interorgan transport of amino acids in dogs. Am J Physiol 222, 1333-1342

Fafournoux $P$, Rémésy $C$, Demigné $C$ (1982) Stimulation of amino acid transport into liver cells from rats adapted to a high-protein diet. Biochem J 206, 13-18

Fafournoux P, Rémésy C, Demigné C (1983) Control of alanine metabolism in rat liver by transport processes or cellular metabolism. Biochem J 210, 645-652

Galibois I, Simoes Nunes C, Rérat A, Savoie L (1989) Net appearence of amino acids in portal blood during digestion of casein or rape- 
seed proteins in the pig. Can J Physiol Pharmacol 67, 1409-1417

Gelfand RA, Glickman MG, Jacob R, Sherwin RS, De Fronzo RA (1986) Removal of infused amino acids by splanchnic and leg tissues in humans. Am $J$ Physiol 250, E407E413.

Ishida T, Chou J, Lewis RM, Hartley CJ, Entman M, Field JB (1983) The effect of ingestion of meat on the hepatic extraction of insulin and glucagon and hepatic glucose output in conscious dogs. Metab Clin Exp 32, 558-567

Kaplan DH, Pitot HC (1970) The regulation of intermediary amino acid metabolism in animal tissues. In: Mammalian Protein Metabolism IV (Munro HN, ed) Academic Press, New York, 388-443

Lomax MA, Baird GD (1983) Blood flow and nutrient change across the liver and gut of the dairy cow. Effects of lactation and fasting. $\mathrm{Br}$ J Nutr 49, 481-496

Pere MC, Gilbert M, Assan R, Battaglia FC (1987) Studies of gut and hepatic metabolism in conscious rabbits. Am J Physiol 252, E573-E580

Rérat A, Vaissade P, Vaugelade $P$ (1979) Absorption kinetics of amino acids and reducing sugars during digestion of barley and wheat meals in the pig: preliminary data. Ann Biol Anim Biochim Biophys 19, 739-747

Rérat A, Vaugelade $P$, Villiers $P$ (1980) A new method for measuring the absorption of nutrients in the pig: critical examination. In: Current Concepts on Digestion and Absorption in Pigs (Low AG, Partridge IG, eds) NIRD, HRI, Ayr, Tech Bull 3, 177-216
Rérat A, Vaissade $P$, Vaugelade $P$ (1984) Absorption kinetics of some carbohydrates in conscious pigs. 2. Quantitative aspects. $\mathrm{Br} J$ Nutr 51, 517-529

Rérat A, Chayvialle JA, Kandé J, Vaissade P, Vaugelade $P$, Bourrier T (1985) Metabolic and hormonal effects of test meals with various protein contents in pigs. Can J Physiol Pharmacol 63, 1547-1559

Rödjmark S, Bloom G, Chou MCY, Jaspan JB, Field JB (1978) Hepatic insulin and glucagon extraction after their augmented secretion in dogs. Am J Physiol 235, E88-E96

Simoes Nunes C, Rérat A, Vaugelade P, Vaissade $P$ (1984) Étude simultanée de bilans d'absorption intestinale et de métabolisation hépatique chez le porc éveillé. Mise au point et intérêt de la technique. Diabète \& Métab 10,349

Simoes Nunes $C$, Rérat $A$, Galibois I, Vaugelade P, Vaissade P (1989) Hepatic and gut balances of glucose, amino-nitrogen, ammonia and urea in the pig after ingestion of casein or rapeseed proteins. Nutr Rep Int 40, 901-907

Snedecor GW, Cochran WG (1967) Statistical Methods. lowa State University Press, Ames, IA

Wahren J, Felig P, Hagenfeldt $L$ (1976) Effect of protein ingestion on splanchnic and leg metabolism in normal man and in patients with diabetes mellitus. J Clin Invest 57, 987-999

Windmueller HG, Spaeth AE (1980) Respiratory fuels and nitrogen metabolism in vivo in small intestine of fed rats. Quantitative importance of glutamine, glutamate and aspartate. $J$ Biol Chem 225, 107-112 